This item was submitted to Loughborough's Research Repository by the author.

Items in Figshare are protected by copyright, with all rights reserved, unless otherwise indicated.

\title{
Ethno-national ties and international business opportunity exploitation: The role of environmental factors
}

PLEASE CITE THE PUBLISHED VERSION

https://doi.org/10.1016/j.ibusrev.2018.08.001

\section{PUBLISHER}

(C) Elsevier

\section{VERSION}

AM (Accepted Manuscript)

\section{PUBLISHER STATEMENT}

This paper was accepted for publication in the journal International Business Review and the definitive published version is available at https://doi.org/10.1016/j.ibusrev.2018.08.001.

\section{LICENCE}

CC BY-NC-ND 4.0

\section{REPOSITORY RECORD}

Kim, Daekwan, Kyuyeong Choi, R. Jean, and John Cadogan. 2018. "Ethno-national Ties and International Business Opportunity Exploitation: The Role of Environmental Factors". Loughborough University. https://hdl.handle.net/2134/35196. 


\title{
Ethno-national Ties and International Business Opportunity Exploitation: The Role of Environmental Factors
}

\begin{abstract}
This paper examines the effect of ethnic populations on international opportunity exploitation at a societal, or national, level. Past research shows a relationship between ethnic ties and international opportunity at an individual level; however, little is known about the role of ethnic ties and international opportunity at a national level, which is called 'ethno-national ties' in this study. In order to acquire in-depth knowledge of this subject, we studied a population of Chinese who are living outside their home country and applied contingency theory principles to investigate environmental boundary conditions that affect this population. Data collected from Chinese exporters indicate an overall positive effect of ethno-national ties on international opportunity exploitation — an effect that is influenced by three moderating variables: technological turbulence, psychic distance, and export barriers. Technological turbulence and export barriers weaken the effect of ethno-national ties on international opportunity exploitation while psychic distance enhances the effect.
\end{abstract}

Keywords: Ethno-national ties (ethnic ties), international opportunity exploitation, technological turbulence, psychic distance, export barriers, contingency theory 


\section{Ethno-national Ties and International Business Opportunity Exploitation: The Role of Environmental Factors}

\section{Introduction}

Over that last four decades, there has been a continual influx of new ethnic groups into the Western countries (Aldrich \& Waldinger, 1990; Guercini, Milanesi, \& Ottati, 2017; Karreman, Burger, \& Van Oort, 2016). New ethnic groups represent new labor forces with new ideas and ways of thinking that have the potential to broaden the scope of business opportunities in the host country. New ethnic groups also facilitate international trade between their home and host countries and take on the role of cultural and economic diplomats who help local entrepreneurs to understand business opportunities that are available in the home countries (Butler \& Herring, 1991). Yet, the literature has remained mute on the possible contributions such ethnic groups make to international business activities of firms (Karreman et al., 2016; Ram \& Jones, 1998; Rauch \& Trindade, 2002).

The unique business opportunities presented by such ethnic groups have become more prevalent with the emergence of information technology that leads to a single, huge, borderless marketplace through globalization, which means tremendous opportunities for entrepreneurs and multinational corporations (MNCs). While recognition and exploitation of international market opportunities has played a critical role in the success of entrepreneurship according to the literature (Baron, 2006; Brown, Davidsson, \& Wiklund, 2001; Busenitz, 1996; Choi \& Shepherd, 2004; Eckhardt \& Shane, 2003; Foss, Lyngsie, \& Zahra, 2013; Nieto \& González-Álvarez, 2016; Short, Ketchen, Shook, \& Ireland, 2010), the cultural and economic diplomacy ethnic groups practice in the host country coupled with the online marketplace deserves research attention with 
potential to make contributions to our understanding on how such opportunities are fully exploited by international entrepreneurs.

Many researchers have attempted to comprehend the role of opportunity recognition/exploitation and its consequences and antecedents (Ahuja, 2000; Baron, 2006; Chandra, Styles, \& Wilkinson, 2009; Ellis, 2011; Kuckertz, Kollmann, Krell, \& Stöckmann, 2017; Ma, Huang, \& Shenkar, 2011; Ozgen \& Baron, 2007; Shane, 2000). In an effort to examine drivers and outcome variables of ethnic ties and international opportunity, those studies have focused on various types of ethnic ties (i.e., business and personal ethnic ties) and their impact on opportunity recognition and exploitation. However, no significant studies discuss its impact on the exploitation of international business opportunities of ethnic ties at a societal or country level, which this study refers to as ethno-national ties. Ethno-national ties in this study expands the concept of ethnic ties that is discussed at the firm or individual level in the literature to the country level, focusing on its effect on international opportunity exploitation.

This study further explores the boundary conditions of the effects of ethno-national ties on international opportunity exploitation. This study argues that the potentially beneficial effect of ethno-national ties on opportunity exploitation may be reduced or enhanced by specific environmental factors. As recognized by the contingency theory, this study includes three environmental variables: technological turbulence, psychic distance, and export barriers (Balachandra \& Friar, 1997; Hofer, 1975; Lee, Chen, Kim, \& Johnson, 2008; Ruekert, Walker Jr, \& Roering, 1985; Sheng, Zhou, \& Li, 2013) as shown in Figure 1.

Insert Figure 1 here

\section{Theoretical Background and Hypothesis Development}




\section{Ethno-national Ties as a Role of Ethnic Diplomacy}

While the literature examines multiple types of ties (e.g., personal, political, business, social, network), the associated research has focused specifically on discussing business and personal ties on opportunity recognition and exploitation (Ellis, 2011; Ma, et al., 2011; Ozgen \& Baron, 2007). For instance, Ma, et al. (2011) examined the effect of social networks on opportunity recognition in cross-national cultural contexts (i.e., Taiwan and United States). The national cultural dimension (individualism-collectivism) moderated the relationship between tie strength, structural holes, and opportunity recognition. Another study found that personal tiebased opportunities can lead to more valuable exchanges that are constrained geographically, perceptually, and linguistically (Ellis, 2011). That is, the recognition of opportunity can be influenced by entrepreneurs' existing social (personal-level) ties with others (Ellis, 2011). Ozgen and Baron (2007) examined multiple source ties (i.e., mentors, informal industry networks, close relationships such as family/friends, and participation in professional forums) to gather opportunity-related information and to provide a more micro-economic perspective.

While the personal-level impact of ethnic ties on businesses has received some notice (Ellis, 2011; Ma, et al., 2011; Ozgen \& Baron, 2007), there has been little discussion of this topic as regards upper (e.g., societal or national) levels. As mentioned earlier, the impact of ethnic populations on certain societies has been underestimated (Aldrich \& Waldinger, 1990; Butler \& Herring, 1991; Gao, 2003; Karreman, et al., 2016); therefore, this study attempts to investigate the widespread impact of ethno-national ties on international business opportunity at the societal level.

In this study, ethno-national ties, as a concept, is defined as the sum of potential commonalities among individuals, such as mother tongue, national origins, and region of birth 
(Jean, Tan, \& Sinkovics, 2011). The current study argues that ethnic groups (populations) have the potential to play a diplomatic role in future connections between home and host countries, and that they provide a platform for information/knowledge exchange that serves as a foundation for international opportunity exploitation. In this study, ethno-national ties refer to ties formed between two parties at a societal level: A group of a certain ethnic population disseminates basic information about the home country in the host country (see Table 2).

As entrepreneurship literature has proliferated, studies have shown reciprocal relationships between entrepreneurial endeavors and ethnic groups (Aldrich \& Waldinger, 1990). Studies also supply the following: 1) statistics on self-employment among various racial and ethnic groups (Butler \& Herring, 1991); 2) information on the importance of specific resource limitation and accessibility by enablers (Rosenstein, 1995); and 3) relationships between brand price elasticity and the proportion of specific ethnic group to major population of a country (Mulhern, 1998).

Since this increase of research interest extensively, research focused on the role of ethnic groups in entrepreneurship and international business (IB) has proven to be a popular concept in modernized, multicultural societies (Masurel, Nijkamp, Tastan, \& Vindigni, 2002). For instance, by using mixed methods, Masurel, et al. (2002) suggested that the reason certain ethnic enterprises are more successful than others is. Another study revealed that the characteristics of an ethnic group and its culture in Singapore significantly affected the negotiation styles of managers in that part of the world (Osman-Gani \& Tan, 2002). Rauch and Trindade (2002) suggested that a certain ethnic Chinese population had a positive impact on international trademade evident by a bilateral trade increase of nearly $60 \%$. In addition, Jean et al. (2011) examined the role of personal ethnic ties on FDI location choice and overall firm performance in the 
context of Chinese ethnic groups across countries. Even in the fields of sociology and political science, the important role of ethnic ties has been investigated and highlighted (Leifer, 1981).

While ethnic ties play a key role in influencing firm performance and decision-making regarding FDI location choice, the recognition and exploitation of opportunity is equally important to the success of international businesses (Ram \& Jones, 1998). More specifically, because recognition is not really useful, in itself, to business success if it does not lead to action (Foss, et al., 2013), the study described in this paper utilizes a more fine-grained understanding of ethno-national ties and opportunity exploitation to examine the role of ethnic groups on international opportunity exploitation. Without going beyond the recognition phase (i.e., the exploitation or realization phase), recognizing opportunities seems to be regarded as just finding an initial starting point-nothing more, nothing less. In focusing on a much more end-point phase that is closer to performance outcome (Pérez-Luño, Wiklund, \& Cabrera, 2011), the authors of the current study suggest that how to exploit, in reality, is much more important than how to recognize. In addition, by looking into the exploitation phase, the recognition phase can be roughly estimated, depending on whether the recognition of the opportunity was estimated correctly and properly. In the following section, opportunity exploitation and its relationship with ethno-national ties is thoroughly discussed.

\section{International Opportunity Exploitation}

Recognizing and exploiting opportunity is critical to the success of most businesses, especially when speaking of entrepreneurship and research and international (or global) business contexts, (Eckhardt and Shane, 2003). For years, many researchers have encountered a lack of consensus on the conceptualization of opportunity (Davidsson, 2015). This has led to a debate about the definitions of 'discovery,' 'recognition,' and 'creation' in regards to entrepreneurial 
ventures (Alvarez \& Barney, 2007). Although Eckhardt and Shane (2003, P. 336) provided one of the most widely used definitions of opportunity— "situations in which new goods, services, raw material, markets and organizing methods can be introduced through the formation of new means, ends or means-ends relationships"- experts continue to debate of the meaning of the conceptualized word.

Interestingly, many researchers (Cha \& Bae, 2010; Eckhardt \& Shane, 2003; Hills, Lumpkin, \& Singh, 1997; Kuckertz, et al., 2017; Ma, et al., 2011; Nicolaou, Shane, Cherkas, \& Spector, 2009; Siegel \& Renko, 2012) agreed that the entrepreneurial process is multifaceted and variegated, but in different ways. For instance, some researchers claimed that 'opportunity' has three dimensions, or phases: discovery, evaluation, and realization (Cha \& Bae, 2010; Eckhardt \& Shane, 2003). Another research stream focused on a two-dimensional approach, explaining that opportunity is, in reality, recognition and exploitation (Hills, et al., 1997; Kuckertz, et al., 2017; Ma, et al., 2011; Nicolaou, et al., 2009; Nieto \& González-Álvarez, 2016; Siegel \& Renko, 2012). Although the two camps of researchers provided different numbers of opportunity phases, both groups identify a phase in which opportunities (existing or potential) are captured and a phase in which opportunities are incorporated, successfully, into reality. That is, realization and exploitation are the phases that follow recognition or discovery. The study outlined in this paper centers on the exploitation aspect of opportunity, and for multiple reasons: 1) Firm performance is strongly associated with the exploitation of opportunities (Pérez-Luño, et al., 2011); 2) Recognition, without exploitation, might be regarded as failure of a certain trial; and 3) The discovery of how ethno-national ties can affect international opportunity exploitation is one of the main purposes of this study. 
More specifically, the current study attempts to examine 'international opportunity exploitation,' or the relationship between ethnic groups and opportunity exploitation as viewed through a global lens and with recognition of multiple boundary conditions. This definition of international opportunity exploitation was adapted from previous work in which the researchers define opportunity exploitation as, "the deployment of resources, actions, and investments to realize recognized opportunities” (Foss, et al., 2013). Such a definition suggests that the exploitation phase is different from the opportunity recognition phase. The operationalization of international opportunity exploitation—a dependent variable in the current study—is discussed in the measure section of this document.

According to past literature, entrepreneurs and managers tend to use their personal ties to gather information, search for new business partners, create new ventures, attract investment from external sources, etc. (Jean, et al., 2011). Further, if a country has a higher ethnic ratio of a specific ethnic group, ethnic ties help to gather more business and local environment information, which helps to mitigate uncertainty and risk. Previous literature has shown that ethnic ties help to reduce uncertainty and risk, because ethnic ties ensure access to resources and many stakeholders (Zaheer, Lamin, \& Subramani, 2009). In addition, for initial business success in an international market, many minority firms tend to rely upon ethnic markets and groups even if they do not have a direct connection with or accessibility to the new market (Ram \& Jones, 1998). For further success of the firms, it is suggested that they must jump or break into other markets by obtaining information and receiving help from external sources including those markets’ ethnic groups (Ram \& Jones, 1998). Additionally, high ethno-national ties at the societal level may indicate that a certain market is replete with opportunities for a specific ethnic group and/or ethnic firm. 
As a baseline hypothesis, the authors of this document state that higher ethno-national ties (such as ethnic ties at a societal level) can lead to stronger international opportunity exploitation. While previous research examines the effect of a manager's personal ethnic ties on FDI location choice and firm performance (Jean, et al., 2011), the current study investigates the link between ethno-national ties and international opportunity exploitation via the potential networking resources of an ethnic population.

\section{H1: Ethno-national ties will be positively associated with international opportunity} exploitation.

In spite of significant efforts to comprehend the role of ethnic ties and their effects on various outcome factors (as discussed previously), the kinds of variables that can moderate the predicted positive relationship between ethno-national ties and international opportunity exploitation remain consistent in entrepreneurship and IB literature. In the following section, the main framework of the current study is introduced, based on entrepreneurship and contingency theory. In addition, three moderating factors are thoroughly reviewed for individual justification and are discussed to develop the hypotheses that follow.

\section{Entrepreneurship and Contingency Theory}

Our contingent viewpoint of ethno-national ties on international opportunity is derived from entrepreneurship theory and contingency theory. Entrepreneurship theory indicates that several external factors (e.g., shocks in market, technological and institutional environmental change) can create sets of new information and opportunity through opportunity recognition (or discovery) and exploitation (Eckhardt \& Shane, 2003). That is, from environmental changes derived from an ethnic group or a constructive influx of new information, pioneers or entrepreneurs may recognize and exploit business opportunities that others are unable to see. 
Moreover, according to contingency theory (Venkatraman, 1989), the beneficial effects of ethnic ties on opportunity can be contingent upon some external variables, such as national context (Koufteros, Vonderembse, \& Jayaram, 2005; Lee, et al., 2008; Ma, et al., 2011; Xiao \& Tsui, 2007). Contingency theory has been used in various fields, such as marketing (Balachandra \& Friar, 1997; Koufteros, et al., 2005; Lee, et al., 2008; Ruekert, et al., 1985; Sheng, et al., 2013), management (Hofer, 1975; Luthans \& Stewart, 1977; Ma, et al., 2011), and management information systems (MIS) (Balachandra \& Friar, 1997; Xiao \& Tsui, 2007). In order to understand the international context and opportunity exploitation phase more clearly, the current study establishes a main framework to examine the baseline relationship between ethno-national ties and international opportunity exploitation with multiple moderating variables.

In this framework, we focus on environmental (contextual) factors. According to the interactive fit argument derived from contingency theory (Venkatraman, 1989), the impact of external sources (e.g., information, knowledge, etc.) on international opportunity exploitation (e.g., new product launch or development) can be more effective and meaningful depending upon the context in which it occurs (Lee, et al., 2008). For instance, globalization trends and technological development can create environmental turbulence, which may alleviate or strengthen the effect of ethnic ties on opportunity exploitation. Therefore, the current study contains three environmental external variables (technological turbulence, psychic distance, and export barriers) and explores potential boundary conditions on the relationship between ethnonational ties and international opportunity exploitation. These moderating variables are individually justified and hypothesized in the following sections.

\section{Technological Turbulence}


As one of well-known environmental influencers in entrepreneurship literature, technological turbulence is a major variable that can bring enormous change to a firm's choices and directions for the future (Kuivalainen, Sundqvist, Puumalainen, \& Cadogan, 2004). Especially in a high-tech industry, technological turbulence as an environmental factor is critical in shaping a firm's successful strategy and activities which can lead to a firm’s performance and outcomes significantly (Lee, et al., 2008). Thus, the current study includes technological turbulence as a first moderating variable.

In this study, technological turbulence refers to the speed of change and technological unpredictability in a specific industry (Jaworski \& Kohli, 1993). A rapid change in a technological environment creates opportunity for developing new products and revealing opportunity in new marketplaces (Jean, Sinkovics, \& Hiebaum, 2014; Lee, et al., 2008). High technological turbulence is characterized by high speed with uncertainty and unpredictability.

In terms of the influence of technological turbulence on a relationship between informal industrial ties and entrepreneurial performance, a recent study used meta-analysis to find that a weak tie is more useful to entrepreneurs when making decisions in a high-technological turbulence (Stam, 2010). So, some strong personal ties can act as a hindrance to entrepreneurs and managers in a certain national context (e.g., the United States), impeding the ability to make an adequate and immediate decision or to identify opportunity identification (Ma, et al., 2011). It is obvious that in a fast-changing environment (i.e., high technological turbulence), the quick acquirement of information and the application of the obtained information play a key role to success (Lee, et al., 2008). This signifies that under these circumstances, managers and entrepreneurs need to process information quickly and apply this acquired information to their own situation in a timely manner. 
Interestingly, in this chaotic, rapidly changing situation, companies or managers that share ethnic ties might rely on these ties more than they should. They may count on the ethnic ties to explore international business opportunities more frequently than they would without the ethnic ties. However, seemingly meaningful and reliable cues from ethnic-national ties might work in a detrimental way under the high technological turbulence context. For instance, ethnonational ties may offer a good source of information to managers and decision makers, but perhaps not in a timely manner. This is not helpful to these individuals when they are faced with the sudden decision whether or not to exploit entrepreneurial opportunity according to immediate changes in the marketplace and buyer's preference (or requirement).

In short, under high technological turbulence, market situation, regulation, and technology can be readily changed and need to be adapted to new market situations very quickly. Hence, information acquired via ethno-national ties might be inadequate, non-applicable, or even useless for the newly changed market situation. On the other hand, under low technological turbulence, there might be enough of a time-window to properly apply information that comes to a firm through ethnic ties. In this paper, we argue that under high technological turbulence, the effect of ethnic ties on international opportunity exploitation is weaker than under low technological turbulence:

H2: Technological turbulence will negatively affect the relationship between ethnonational ties and international opportunity exploitation.

\section{Psychic Distance}

The second external factor that is considered in this study is psychic distance. In an international business context, cross-national perspective is necessarily required in order to better 
realize international business opportunities and to avoid the potential failure of cross-border business dealings. In a global market, in particular, psychic distance is an essential factor to be considered if a transaction occurs between two different countries (i.e., the home country and host country), or whenever decision-makers feel that there is a "gap" between the two countries. International business literature widely accepts psychic distance as a potential factor in affecting a decision-maker's perceptual distance (Baack, Dow, Parente, \& Bacon, 2015). When it comes to considering entrepreneurs' or managers' opportunity recognition and exploitation, perceptional psychic distance has the potential to play a significant role in decision-making. Hence, this perceptual barrier-psychic distance—is included as a second moderator in the current study.

Researchers have examined the definition of 'psychic distance' since its earliest use, by Baack, et al. (2015); Ellis (2008); Puthusserry, Child, and Rodrigues (2014); Shoham and Albaum (1995); Sinha, Wang, Scott-Kennel, and Gibb (2015); Stottinger and Schlegelmilch (1998); Yildiz and Fey (2016). In the mid-70s, Johanson and Wiedersheim - Paul (1975, p. 308) described it as "the sum of factors preventing or disturbing the flow of information between firm and market. Examples of such factors are differences in language, culture, political systems, level of education, level of industrial development, etc.”. This cross-national perspective and clear definition brought a new wave of research trials in international business and opportunity literature to the fore (Baack, et al., 2015).

Previous literature investigated psychic distance as a potential factor affecting a decisionmaker’s perceptual distance (Baack, et al., 2015). Some research focused on a uni-dimensional approach, regarding direct effect of psychic distance on outcome variables. For instance, Sinha, et al. (2015) investigated the paradoxical multidimensional perspective of psychic distance on market entry by using software to study the new, international ventures in New Zealand. Further, 
as a mixed approach, the effect of psychic distance was examined with entrepreneurs' actual behavioral controls (as a mediator and/or moderator) (Dung \& Janssen, 2015), with entry strategy and retail strategy (as mediators) (Evans, Mavondo, \& Bridson, 2008), or with coping strategy and its impact as a cross-national study between Britain and India (Puthusserry, et al., 2014).

Another research group claimed that psychic distance is multifaceted, with at least two dimensions or more. As an example, one study provided an empirical result that showed that separation of the original construct (psychic distance) substantially increases explained variance of financial performance and strategic effectiveness (i.e., explanatory power) (Evans \& Mavondo, 2002). Yildiz and Fey (2016) proposed two different dimensions (extent and effect) of psychic distance in a cross-border M\&A situation between Sweden and China. They claimed that the two dimensions and their effects (as an outcome of the difference) should be differentiated as similarity/difference of extent and (un)favorability of effect (Yildiz \& Fey, 2016). This means that psychic distance can be regarded either positively or negatively, having a favorable or unfavorable effect.

Rather than investigate the direct effect of psychic distance on outcome, the current study examines psychic distance as a moderating variable, due to the fact that the concept of psychic distance has been established and frequently utilized as a moderating variable in international exporting literature (Andersen, 1993; Cavusgil \& Nevin, 1981; Dichtl, Koeglmayr, \& Mueller, 1990; Ellis, 2008; Griffith \& Dimitrova, 2014; Shoham \& Albaum, 1995; Stottinger \& Schlegelmilch, 1998).

Among research that examines the moderating effect of psychic distance, one study suggested that business and cultural psychic distance has different effects on the structuring of 
the export relationship (i.e., complementary of capabilities) (Griffith \& Dimitrova, 2014). In high-psychic-distance situations, when executives or managers perceive the strong difference between their own firm (or home country) and the partner firm's environmental context, they are more likely to be hesitant to start export activities (Griffith \& Dimitrova, 2014).

Another empirical study found that psychic distance moderates the impact of foreign market size on entry sequence in the Chinese context (Ellis, 2008). Due to the fact that limiting information transmissions constrains social networks and international entrepreneurship, longdistance communication and information exchange between a home country and a host country matter as the precondition of communication. These limits and constraints are usually measured based on geographic, cultural, psychic and linguistic distance to foreign markets (Beckerman, 1956; Ellis, 2011; Ghemawat, 2001). It was proposed that these impediments to communication and international exchanges via social ties would lead to the constraint of opportunity recognition and exploitation (Ellis, 2011). Given that common social ties with these impediments play a constrained role, the authors of this paper believe that specific ethnic ties that provide unique and/or quality information and knowledge may mitigate uncertainty (Zaheer, et al., 2009) and, in turn, enhance chances of recognizing and exploiting international opportunity. Unlike technological turbulence, where a speedy information exchange and the rapid application of acquired information matters, unique and quality information is the only thing that matters when the gap between home country and host country is high (as with high psychic distance).

Further, increased psychic distance may cause an increase in uncertainty over operational contexts and/or future plans. Normally, managers are more likely to hesitate to exploit new business opportunities abroad when they perceive a large gap between two countries (the home 
country and the host). There is no room for blind luck; intentional trial and effort is requisite (Ellis, 2011).

While the gap between two countries can trigger hesitation, it can also be a starting point for new opportunities and future success. When psychic distance plays an impedimentary role, the role of ethno-national ties must be strengthened and quality information must be collected from the ethnic group in order to minimize uncertainty (Zaheer, et al., 2009). That is, when psychic distance is high, the role and effect of ethno-national ties on international opportunity exploitation is enhanced. Therefore, we posit the following:

H3: Psychic distance will positively affect the relationship between ethno-national ties and international opportunity exploitation.

However, these external factors may not be enough to explain the relationship between ethno-national ties and international opportunity exploitation. Hence, to more deeply examine the relationship, the current study includes a third external environmental variable: export barriers.

\section{Export Barriers}

In the context of international business, why and how some companies are able to export more than others are important questions (Arteaga-Ortiz \& Fernández-Ortiz, 2010). Past literature suggests that research into the issue and influence of export barriers dates back to the 1970s, in the United States (Bilkey, 1978; Kahiya, 2013; Pavord \& Bogart, 1975). Leonidou (1995, p. 31) characterized export barriers as "attitudinal, structural, operative, or other obstacles that hinder or inhibit companies from taking the decision to start, develop or maintain international activity.” Leonidou then divided export barriers into two categories: internal and external export barriers. After his work, the concept and definition of export barriers became 
broader and more generalized: "any element or factor, whether internal or external, that blocks or discourages companies from initiating, increasing, or maintaining export activities.” (Arteaga Ortiz \& Fernández - Ortiz, 2010, p. 397). This definition is utilized in the current study as the definition of export barriers. For at least three decades, export barriers have played a pivotal role on exporting companies in the international market (Arteaga - Ortiz \& Fernández - Ortiz, 2010).

In the past, it was suggested that the direction of future research themes and questions would include the role of context variables in penetrating the international market and in moderating internationalization processes and opportunity (Griffith, Tamer Cavusgil, \& Xu, 2008). When it comes to thinking about global market and international opportunity, export barriers is one of primary variables to contemplate. Depending upon the level of export barriers, decision-makers may change their mind about new markets or speculate on different strategies by which to penetrate target markets.

When the distance of a market from the home country is long, or export barriers are high, the sunk costs incurs based on equilibrium assumption (Buckley, 1996). That is, a firm facing such difficulties is more likely to select a different market or to consider different strategies, or even to discontinue to recognize and exploit an international opportunity. For instance, once exporting costs overwhelm FDI cost or licensing cost, firms become willing to switch to FDI rather than to export (Buckley, 1996). Ethnic groups that are involved in international business ventures may not have proper knowledge about export barriers, regulations, etc. Even if they have some information or knowledge about the barriers, there would be quite not many things to change or help for specific ethnic firms. On the other hand, if export barriers are low, ethnic groups can play a more important role in exporting activities, due to the fact that information and 
support from the ethnic groups is considered useful. When export barriers are high, firms may give up the potential opportunity and decide, instead, to work within their own ethnic group.

Furthermore, when export barriers are high, transactions tend to be much more complicated, and managers may find themselves confronting numerous difficulties, such as slow process of payment, a different type of payment, lack of smooth communication with overseas customers, and difficulty in understanding the needs of foreign customers in regards to new products, etc. (Arteaga-Ortiz \& Fernández-Ortiz, 2010; Kahiya, 2013). This complication of procedure can hinder the role of ethnic groups in opportunity exploitation. That is, the more complicated an exporting procedure is, the more difficulties exporting firms can encounter. Certainly, the procedural complication is something that ethnic groups cannot change or significantly mitigate. The authors of this document believe that under a high-export-barriers situation, ethnic groups via ethno-national ties provide little if any assistance or help with exploiting opportunity. When export barriers are low, however, the ethno-national ties may have a positive effect. Therefore, we argue the following:

H4: Export barriers will negatively affect the relationship between ethno-national ties and international opportunity exploitation.

\section{Control Variable}

In the literature, a firm's size is believed to influence its performance, given that large firms realize synergistic effects from diverse, abundant resources (Wu, Yeniyurt, Kim, \& Cavusgil, 2006). This study incorporates firm size, measured by the total number of employees, as a control variable. This control variable will help us to more effectively identify the impact of ethno-national ties on opportunity exploitation.

\section{Methodology}




\section{Sample}

We employed a survey approach to collect data from the sampled firms and followed the procedures recommended by Churchill (1979) and Anderson and Gerbing (1988). First, we conducted in-depth interviews with senior managers of 15 SMEs - small-medium size enterprises - exporters in China, exploring their Internet and exporting practice. Equipped with an understanding of these practices, we then developed an English version of the survey instrument, translated it into Chinese, and then back-translated in order to ensure conceptual equivalence and reduce bias. Third, we conducted a pretest with 20 SMEs in China. The pretest provided valuable feedback about the survey questions. We then refined the questionnaire and finalized the instrument based on the pretest and interviews.

A random sample of 1,000 firms was drawn from a list of exporting firms in representative provinces and cities across China. A Chinese research company provided the database and the sampling frame for this study. We collaborated with a local research firm in 2014 to have trained interviewers administer the survey through personal and telephone interviews. We used a key informant approach to conduct our survey and to reduce survey costs. A senior manager (e.g., CEO or export manager) in charge of exporting was chosen in each firm as the key informant.

In total, we received 280 questionnaires, for a response rate of $28 \%$. After dropping those firms that were missing values or did not meet our definition of SMEs, we were left with 250 useable responses. Non-response bias was assessed by classifying responses into two groups: early responses and late responses (Armstrong \& Overton, 1977). Independent t-tests on demographic variables, such as revenue and employee number, were performed. No significant 
difference was identified. Hence, non-response bias does not pose a major problem to the study (Armstrong \& Overton, 1977).

In order to minimize common method bias and casual inference, we used a longitudinal research design (Rindfleisch, Malter, Ganesan, \& Moorman, 2008). Following previous work (Boso, Story, \& Cadogan, 2013), we made another round of data collection for the dependent variable_-export performance_-one year after the initial data collection for our independent variables and mediator. We contacted 250 firms for the second wave of data collection. Of 250, 130 provided their responses. We included those 130 complete responses from two separate data collections with a time-lag in our analysis.

Table 1 provides the demographic information of the 130 participating firms that were included in the analysis. All of the firms in the sample are privately owned Chinese companies. In addition, the average age of the firms is 10.3 years, indicating a relatively new start-up. The mean number of full-time employees is 143.6. These firms are export-oriented, as indicated by their high average export percentage of 59.3 percent. The mean number of foreign markets is 15.9. Regarding industrial background, most of these firms are in the high-tech industries (i.e., hardware and electronics). The rest of them are from various industries (e.g., apparel, textiles/accessories, shoes, gifts, sports/toys, health/beauty, packaging, and advertising/office).

\section{Insert Table 1 here}

\section{Measure}

The instrument of measurement was established in multiple stages. A multi-item format (seven-point Likert scale) was used to operationalize all constructs and variables in the current study, with the exception of ethno-national ties. The scales for all of the study constructs were 
adapted from the extant literature when possible. Refinements were based on feedback and the advice of fully experienced researchers in the area of inquiry. Table 2 displays all of the measure items and constructs used in the current study.

The independent variable, ethno-national ties, was operationalized by calculating the ratio of the Chinese ethic population to the total population in each country that has been entered by the companies in our sample. While the variable is operationalized at the country level, it is not uncommon in the literature to use country-level independent or moderating variables in the studies on international business phenomena. Such variables include cultural distance (Hofstede, 2003; Hoftstede, 1980), context of communication (Hall, 1989), psychic distance, institutional distance, and knowledge distance, to name a few. A full literature review and list of variables at the country level in the international business can be found in (Berry, Guillén, \& Zhou, 2010). The scale for opportunity exploitation was adapted from past work (Foss, et al., 2013). We also adapted the measure of technological turbulence from Jaworski and Kohli (1993). The measurement scale for psychic distance was adapted from the work of Katsikeas, Skarmeas, and Bello (2009). Lastly, the export barriers scale was adopted from Arteaga - Ortiz and Ferná ndez - Ortiz (2010).

Insert Table 2 here

\section{Analysis and Results}

First, we assessed the measurement model by conducting confirmatory factor analysis (CFA) using Amos 22. During the purification process, any measurement items not significantly loading on the respective construct or cross-loading on more than one construct were removed to improve the convergent and discriminant validity. The fit indexes of the final CFA model 
include Chi-square $=129.417$ with 71 d.f., $\mathrm{CFI}=.921, \mathrm{IFI}=.923, \mathrm{RMSEA}=.080$, and SRMR $=.063$, indicating a 'close' to 'good' fit. The results show that all items in the CFA model have a significant loading with the lambda around or greater than .70, as the literature suggests. We also calculated Average Variance Extracted (AVE) using the formula suggested by Fornell and Larcker (1981). According to the results, all of the study constructs show a good level of convergent validity, with their AVE greater than .50, as shown in Table 3. The share variances calculated by squaring the correlations remained less than the respective AVEs, revealing an adequate level of discriminant validity. As for the construct reliability, we calculated Composite Reliability (CR) using the lambdas (Fornell \& Larcker, 1981). The composite reliabilities were all greater than .80 as reported in Table 2, supporting a good level of construct reliability for the study constructs (Bernstein \& Nunnally, 1994).

Insert Tables 3 \& 4 here

With the good measurement model, we proceeded to estimate the study model using the Ordinary Least Square (OLS) regression analysis. The OLS regression minimizes information loss in the forced median-split process that is typically involved in SEM-based multi-group analyses that use a continuous variable. In the regression analysis, we estimated three hierarchically nested models to highlight the effects of three moderators clearly. In the first model, we added the control variable, firm size, only to the model. The effect of firm size was not significant with R-square $=.001$. In the second model, the main effect variables including ethno-national ties, technological turbulence, psychic distance, and export barriers are added to the analysis. According to the results, those main effects are not statistically significant except for technological turbulence, which was significant at 10 percent with the model R-square 
$=.043$. In the final model, the moderating effects of technological turbulence, psychic distance, and export barriers are added to the second model. For the model, the moderators are created by meaning centering the variables first to minimize potential multicollinearities between the main effects and interaction terms (Aiken, West, \& Reno, 1991; Cohen \& Cohen, 1983) and then took the product of the independent variable and moderator for each of those interaction terms (Aiken, et al., 1991; Cohen \& Cohen, 1983). The model has R-square of .146, revealing a visible improvement from the second model, indicating the significant role of three moderating variables and the effect of ethno-national ties in the presence of those three moderators. We use the result of the third model to test the hypotheses as it has all of the main effect variables and interaction terms specified best replicating the real world situation. The regression results show that the positive effect of ethno-national ties on international opportunity exploitation is significant ( $\beta=.129, p<.10$ ), as reported in Table 4. Thus, Hypothesis 1 (H1) is supported.

Insert Figure 2 here

In terms of the moderating effects (i.e., technological turbulence, psychic distance, and export barriers), the results indicate that all three associated hypotheses are supported (See Figure 2). Specifically, the interaction between technological turbulence and ethno-national ties is significant and negative ( $\beta=-.235, p<.05)$, supporting $\mathrm{H} 2$. In addition, psychic distance makes the impact of ethno-national ties on international opportunity exploitation stronger with its result of $\beta=.227$ ( $p<.05$ ), lending support for H3. Furthermore, the interaction of export barriers with ethno-national ties was found to significantly weaken the impact of ethno-national ties on international opportunity exploitation $(\beta=-.269$, $\mathrm{p}<.05)$. This result supports $\mathrm{H} 4$. Finally, the control variable—firm size—has an insignificant effect on international opportunity 
exploitation, with $\beta=.033(p>.10)$. The adjusted R-square of the model is .146. To visualize the role of these three moderators, we developed Figures 3-5.

Insert Figures 3-5 here

\section{Discussion}

Ethnic ties have become a key issue for many global companies (i.e., multinational companies or multinational enterprises) and societies (Aldrich \& Waldinger, 1990; Butler \& Herring, 1991; Li, Isidor, Dau, \& Kabst, 2017; Rosenstein, 1995; Wei, 2007). In the area of entrepreneurship, in particular, the strength or weakness of ethnic ties has emerged as a critical factor when researchers examine international opportunity, foreign direct investment with location choice, and new business (Gao, 2003; Jean, et al., 2011; Karreman, et al., 2016). Nonetheless, the current literature on ethnic ties and international opportunity exploitation has been fragmented and lacked diverse empirical supports to provide deeper understanding of boundary conditions (or moderating variables). The current study examines the fundamental but critical relationship between ethno-national ties and international opportunity exploitation at a societal level empirically, with multiple moderating variables. Certainly, there is clear difference between the current study and past research in terms of ethnic ties and international opportunity. This difference can be summarized by stating that the current study emphasizes the role of ethnonational ties and investigates the effect of ethno-national ties on international opportunities exploitation at a societal level.

To the best of our knowledge, the current study is a pioneering study that provide insight into the role of ethnonational ties on opportunity exploitation with multiple boundary conditions. One exceptional study that was conducted to investigate bilateral effects of ethnic ties on firm 
performance and trade at community level (Rauch \& Trindade, 2002) revealed that specific ethnic networks (e.g., China) are able to increase international trade between two countries. Another study based on Taiwanese firms discussed the role of ethnic ties on international opportunity (i.e., firm performance) at a personal level (Jean, et al., 2011). However, the purpose of this study was to investigate how the personal ethnic ties of managers can affect FDI location choice and firm performance. Our study provides a unique contribution to the literature on ethnic ties and international opportunity exploitation at an upper level. The results of our analysis show a positive effect of ethno-national ties on international opportunity exploitation. Regardless of firm size, it is not uncommon for firms to target existing or new markets where their own specific ethnic groups are prevalent or dominant (Ram \& Jones, 1998). The bigger ethnic groups are, the more international business opportunities the home country firms get.

In addition to proving the positive relationship between ethno-national ties and international opportunity exploitation at a different level, several moderating variables were examined and discussed in this study. First, one of the most widely used constructstechnological turbulence —-was selected as the first moderating variable. As expected, technological turbulence (an environmental factor) negatively moderates the effect of ethnonational ties on international opportunity exploitation. In a chaotic, fast-changing situation, the role of an ethnic group (via ethnic ties) seems to be constrained. According to previous research, weak ethnic ties in a high technological turbulence context are more useful when entrepreneurs and managers need to make quick decisions (Stam, 2010). This indicates that the rapid acquirement and application of the information from a specific route (e.g., ethno-national ties) is critical under circumstances of high technological turbulence. Our result supports the idea that when a firm run its business in a highly turbulent technological industry, the firm needs to focus 
more on speed rather than on quality of information. Of course, quality information and knowledge is definitely important, but it is only useful when acquired and applied in a timely manner.

On the other hand, high psychic distance can cause entrepreneurs or managers who look for attractive international opportunities to view infrastructure, regulations, and even language as insurmountable obstacles. However, while psychic distance is more likely to be treated as a barrier, that is not always the case: For example, in a context of high psychic distance, an ethnic group can provide managers with unique, quality information and knowledge. In a context of low psychic distance, however, managers may end up believing that they know enough about a target market, causing them to dismiss resources that are the result of specific ethno-national ties. Moreover, unlike technological turbulence, where speed of application and information acquirement do matter, a lack of quality and unique information can have much more of an impact on high- and low-psychic-distance contexts. We believe that when entrepreneurs and managers feel a wide gap, the ethno-national ties will be regarded as auspicious, and ethnic groups will have more of a chance to provide resources, knowledge, and quality information that managers and entrepreneurs need. We found that in the high-psychic-distance context, ethnonational ties offer quality and unique information, which positively affects international opportunity exploitation.

Lastly, as we expected, the relationship between ethno-national ties and international opportunity exploitation is negatively moderated by the third moderating variable: export barriers. Whereas psychic distance indicates the perceptual gap between home and host country, export barriers refer to numerous existing difficulties, such as working with unfamiliar financial systems, dealing with communication difficulties, and understanding the needs of specific 
markets in regards to new products (Buckley, 1996; Griffith, et al., 2008; Leonidou, 2004;

Rutihinda, 2008). We believe that entrepreneurs and managers experience more difficulties in procedures and transactions when a target market is far away, geographically, and export barriers are high.

To managers and firms seeking international opportunities and globalized business, we say that through this study, we demonstrated the role of ethno-national ties in global ethnic diplomacy as relates to international business. We also showed that technological turbulence is not an obstacle; rather, it gives entrepreneurs and managers a chance to recognize and exploit promising international opportunities. Of course, the acquisition of useful, timely information from ethno-national ties is not the only key to success. This study shows that high technological turbulence suppresses the positive effect of ethno-national ties on international opportunity exploitation. That is, when an industry exhibits high technological turbulence, entrepreneurs and managers must acquire and exploit helpful information—-the source of which is ethno-national ties—in a timely manner.

Yet another environmental factor to consider is psychic distance. While a high psychic distance might prevent managers from discovering international opportunities, high psychic distance is not always an absolute suppressor or hindrance to international trade and business. The results of this study show that within a context of high psychic distance, an ethnic group can boost the chances of a business exploiting international opportunity through ethno-national ties. Firms and managers need to view their own ethno-national ties as a tool to discover and exploit attractive international opportunities when psychic distance is high.

Lastly, when a firm has high export barriers, the positive impact of ethno-national ties weakens. This study suggests that procedural complications caused by export barriers lead to 
significant difficulties for managers, even if favorable ethno-national ties and ethnic groups exist. Hence, firms need to move forward more actively and aggressively by utilizing their external ethnic ties in the market where export barriers are more manageable.

\section{Limitations and Future Research}

This study adds to entrepreneurship literature and advances the in-depth knowledge of ethnic ties (groups) on international opportunity exploitation. However, this study also provides a set of limitations and suggestions for future research. First of all, this empirical study only examines one type of ties, ethnic-national ties, in electronic markets. Future research may attempt to compare the effect of different types of ties (e.g., political, ethnic, and informal academic) on industrial opportunity and firm performance. Second, we demonstrated only one direct relationship between ethno-national ties and international opportunity exploitation; for future research, a nomological order of ethno-national ties would provide a great opportunity to

shed light on ethnicity and opportunity literature (e.g., financial performance, driver of ethnicity, etc.). Lastly, the current study focused on the relationship between ethno-national ties and international opportunity exploitation in one specific context: Chinese. Future research may confirm the link in other contexts. 


\section{References}

Ahuja, G. (2000). The duality of collaboration: inducements and opportunities in the formation of interfirm linkages. Strategic Management Journal, 21, 317-343.

Aiken, L. S., West, S. G., \& Reno, R. R. (1991). Multiple regression: Testing and interpreting interactions: Sage.

Aldrich, H. E., \& Waldinger, R. (1990). Ethnicity and Entrepreneurship. Annu. Rev. Social, 111-135.

Alvarez, S. A., \& Barney, J. B. (2007). Discovery and creation: alternative theories of entrepreneurial action. Strategic Entrepreneurship Journal, 1, 11-26.

Andersen, O. (1993). On the internationalization process of firms: A critical analysis. Journal of International Business Studies, 24, 209.

Anderson, J. C., \& Gerbing, D. W. (1988). Structural equation modeling in practice: A review and recommended two-step approach. Psychological bulletin, 103, 411.

Armstrong, J. S., \& Overton, T. S. (1977). Estimating Nonresponse Bias in Mail Surveys. Journal of Marketing Research, 14, 396-402.

Arteaga - Ortiz, J., \& Fernández - Ortiz, R. (2010). Why don't we use the same export barrier measurement scale? An empirical analysis in small and medium - sized enterprises. Journal of Small Business Management, 48, 395-420.

Baack, D. W., Dow, D., Parente, R., \& Bacon, D. R. (2015). Confirmation bias in individual-level perceptions of psychic distance: An experimental investigation. Journal of International Business Studies, 46, 938-959.

Balachandra, R., \& Friar, J. H. (1997). Factors for success in R\&D projects and new product innovation: a contextual framework. IEEE Transactions on Engineering management, 44, 276-287.

Baron, R. A. (2006). Opportunity Recognition as Pattern Recognition: How Entrepreneurs "Connect the Dots" to Identify New Business Opportunities. Academy of Management Perspectives, 20, 104119.

Beckerman, W. (1956). Distance and the pattern of intra-European trade. The review of Economics and Statistics, 31-40.

Bernstein, I. H., \& Nunnally, J. (1994). Psychometric theory. New York: McGraw-Hill. Oliva, TA, Oliver, RL, \& MacMillan, IC (1992). A catastrophe model for developing service satisfaction strategies. Journal of Marketing, 56, 83-95.

Berry, H., Guillén, M. F., \& Zhou, N. (2010). An institutional approach to cross-national distance. Journal of International Business Studies, 41, 1460-1480.

Bilkey, W. J. (1978). An attempted integration of the literature on the export behavior of firms. Journal of International Business Studies, 9, 33-46.

Boso, N., Story, V. M., \& Cadogan, J. W. (2013). Entrepreneurial orientation, market orientation, network ties, and performance: Study of entrepreneurial firms in a developing economy. Journal of Business Venturing, 28, 708-727.

Brown, T. E., Davidsson, P., \& Wiklund, J. (2001). An operationalization of Stevenson's conceptualization of entrepreneurship as opportunity-based firm behavior. Strategic Management Journal, 22, 953-968.

Buckley, P. J. (1996). The Role of Management in International Business Theory1: A Meta-Analysis and Integration of the Literature on International Business and International Management. Management International Review, 36, 7-54.

Busenitz, L. W. (1996). Research on entrepreneurial alertness. Journal of Small Business Management, $34,35-44$

Butler, J. S., \& Herring, C. (1991). Ethnicity and Entrepreneurship in America: Toward an Explanation of Racial and Ethnic Group Variations in Self-Employment. Sociological Perspectives, 34, 79-94. 
Cavusgil, S. T., \& Nevin, J. R. (1981). Internal Determinants of export marketing behavior: An empirical investigation. JMR, Journal of Marketing Research (pre-1986), 18, 114.

Cha, M.-S., \& Bae, Z.-T. (2010). The entrepreneurial journey: From entrepreneurial intent to opportunity realization. The Journal of High Technology Management Research, 21, 31-42.

Chandra, Y., Styles, C., \& Wilkinson, I. (2009). The recognition of first time international entrepreneurial opportunities. International Marketing Review, 26, 30-61.

Choi, Y. R., \& Shepherd, D. A. (2004). Entrepreneurs' Decisions to Exploit Opportunities. Journal of Management, 30, 377-395.

Churchill, G. A., Jr. (1979). A Paradigm for Developing Better Measures of Marketing Constructs. Journal of Marketing Research, 16, 64-73.

Cohen, J., \& Cohen, P. (1983). Applied multiple regression/correlation analysis for the behavioral sciences. Hillsdale, NJ: Erlbaum.

Dichtl, E., Koeglmayr, H.-G., \& Mueller, S. (1990). International Orientation As A Precondition For Export Succ. Journal of International Business Studies, 21, 23.

Dung, N. V., \& Janssen, F. (2015). ENTREPRENEUR'S ACTUAL BEHAVIORAL CONTROLS, PSYCHIC DISTANCE STIMULI, AND EXPORT MODE CHOICE. Journal of Developmental Entrepreneurship, $20,-1$.

Eckhardt, J. T., \& Shane, S. A. (2003). Opportunities and Entrepreneurship. Journal of Management, 29, 333-349.

Ellis, P. D. (2008). Does psychic distance moderate the market size-entry sequence relationship? Journal of International Business Studies, 39, 351-369.

Ellis, P. D. (2011). Social ties and international entrepreneurship: Opportunities and constraints affecting firm internationalization. Journal of International Business Studies, 42, 99-127.

Evans, J., \& Mavondo, F. T. (2002). Psychic distance and organizational performance: An empirical examination of international retailing operations. Journal of International Business Studies, 33, 515-532.

Evans, J., Mavondo, F. T., \& Bridson, K. (2008). Psychic Distance: Antecedents, Retail Strategy Implications, and Performance Outcomes. Journal of International Marketing, 16, 32-63.

Fornell, C., \& Larcker, D. F. (1981). Evaluating structural equation models with unobservable variables and measurement error. Journal of marketing research, 39-50.

Foss, N. J., Lyngsie, J., \& Zahra, S. A. (2013). The role of external knowledge sources and organizational design in the process of opportunity exploitation. Strategic Management Journal, 34, 14531471.

Gao, T. (2003). Ethnic Chinese networks and international investment: evidence from inward FDI in China. Journal of Asian Economics, 14, 611-629.

Ghemawat, P. (2001). Distance still matters. Harvard Business Review, 79, 137-147.

Griffith, D. A., \& Dimitrova, B. V. (2014). Business and Cultural Aspects of Psychic Distance and Complementarity of Capabilities in Export Relationships. Journal of International Marketing, 22, 50-67.

Griffith, D. A., Tamer Cavusgil, S., \& Xu, S. (2008). Emerging themes in international business research. Journal of International Business Studies, 39, 1220-1235.

Guercini, S., Milanesi, M., \& Ottati, G. D. (2017). Paths of evolution for the Chinese migrant entrepreneurship: a multiple case analysis in Italy. Journal of International Entrepreneurship.

Hall, E. T. (1989). Beyond culture: Anchor.

Hills, G., Lumpkin, G. T., \& Singh, R. P. (1997). Opportunity recognition: perceptions and behaviors of entrepreneurs. Frontiers of Entrepreneurship Research, pp. 203-218.

Hofer, C. W. (1975). Toward a contingency theory of business strategy. Academy of Management journal, 18, 784-810. 
Hofstede, G. (2003). Culture's consequences: Comparing values, behaviors, institutions and organizations across nations: Sage publications.

Hoftstede, G. (1980). Culture's consequences: International differences in work-related values. In: London: Sage.

Jaworski, B. J., \& Kohli, A. K. (1993). Market orientation: antecedents and consequences. The Journal of marketing, 53-70.

Jean, R. J., Sinkovics, R. R., \& Hiebaum, T. P. (2014). The effects of supplier involvement and knowledge protection on product innovation in customer-supplier relationships: a study of global automotive suppliers in China. Journal of Product Innovation Management, 31, 98-113.

Jean, R. J., Tan, D., \& Sinkovics, R. R. (2011). Ethnic ties, location choice, and firm performance in foreign direct investment: A study of Taiwanese business groups FDI in China. International Business Review, 20, 627-635.

Johanson, J., \& Wiedersheim - Paul, F. (1975). The internationalization of the firm-four Swedish cases. Journal of Management Studies, 12, 305-323.

Kahiya, E. T. (2013). Export barriers and path to internationalization: A comparison of conventional enterprises and international new ventures. Journal of International Entrepreneurship, 11, 3-29.

Karreman, B., Burger, M. J., \& Van Oort, F. G. (2016). Location Choices of Chinese Multinationals in Europe: The Role of Overseas Communities. Economic Geography, qk93, 131-161.

Katsikeas, C. S., Skarmeas, D., \& Bello, D. C. (2009). Developing successful trust-based international exchange relationships. Journal of International Business Studies, 40, 132-155.

Koufteros, X., Vonderembse, M., \& Jayaram, J. (2005). Internal and external integration for product development: the contingency effects of uncertainty, equivocality, and platform strategy. Decision Sciences, 36, 97-133.

Kuckertz, A., Kollmann, T., Krell, P., \& Stöckmann, C. (2017). Understanding, differentiating, and measuring opportunity recognition and opportunity exploitation. International Journal of Entrepreneurial Behaviour and Research, 23, 78-97.

Kuivalainen, O., Sundqvist, S., Puumalainen, K., \& Cadogan, J. W. (2004). The Effect of Environmental Turbulence and Leader Characteristics on International Performance: Are Knowledge-Based Firms Different? Canadian Journal of Administrative Sciences, 21, 35-50.

Lee, R. P., Chen, Q., Kim, D., \& Johnson, J. L. (2008). Knowledge Transfer Between Multinational Corporations' Headquarters and Their Subsidiaries: Influences on and Implications for New Product Outcomes. Journal of International Marketing, 16, 1.

Leifer, E. M. (1981). Competing models of political mobilization: The role of ethnic ties. American Journal of Sociology, 87, 23-47.

Leonidou, L. C. (1995). Empirical research on export barriers: review, assessment, and synthesis. Journal of International Marketing, 29-43.

Leonidou, L. C. (2004). An Analysis of the Barriers Hindering Small Business Export Development. Journal of Small Business Management, 42, 279-302.

Li, C., Isidor, R., Dau, L. A., \& Kabst, R. (2017). The More the Merrier? Immigrant Share and Entrepreneurial Activities. Entrepreneurship Theory and Practice, n/a-n/a.

Luthans, F., \& Stewart, T. I. (1977). A general contingency theory of management. Academy of Management Review, 2, 181-195.

Ma, R., Huang, Y. C., \& Shenkar, O. (2011). Social networks and opportunity recognition: A cultural comparison between Taiwan and the United States. Strategic Management Journal, 32, 11831205.

Masurel, E., Nijkamp, P., Tastan, M., \& Vindigni, G. (2002). Motivations and Performance Conditions for Ethnic Entrepreneurship. Growth and Change, 33, 238-260. 
Mulhern, F. J. (1998). Variability of Brand Price Elasticities across Retail Stores: Ethnic, Income, and Brand Determinants. Journal of Retailing, 74, 427-446.

Nicolaou, N., Shane, S., Cherkas, L., \& Spector, T. D. (2009). Opportunity recognition and the tendency to be an entrepreneur: A bivariate genetics perspective. Organizational Behavior and Human Decision Processes, 110, 108-117.

Nieto, M., \& González-Álvarez, N. (2016). Social capital effects on the discovery and exploitation of entrepreneurial opportunities. International Entrepreneurship and Management Journal, 12, 507-530.

Osman-Gani, A. M., \& Tan, J.-S. (2002). Influence of culture on negotiation styles of Asian managers: An empirical study of major cultural/ethnic groups in Singapore. Thunderbird International Business Review, 44, 819-839.

Ozgen, E., \& Baron, R. A. (2007). Social sources of information in opportunity recognition: Effects of mentors, industry networks, and professional forums. Journal of Business Venturing, 22, 174192.

Pavord, W. C., \& Bogart, R. G. (1975). The dynamics of the decision to export. Akron Business and Economic Review, 6, 6-11.

Pérez-Luño, A., Wiklund, J., \& Cabrera, R. V. (2011). The dual nature of innovative activity: How entrepreneurial orientation influences innovation generation and adoption. Journal of Business Venturing, 26, 555-571.

Puthusserry, P. N., Child, J., \& Rodrigues, S. B. (2014). Psychic Distance, its Business Impact and Modes of Coping: A Study of British and Indian Partner SMEs. Management International Review, 54, 1-29.

Ram, M., \& Jones, T. (1998). Ethnic minorities in business.

Rauch, J. E., \& Trindade, V. (2002). Ethnic Chinese Networks in International Trade. Review of Economics and Statistics, 84, 116-130.

Rindfleisch, A., Malter, A. J., Ganesan, S., \& Moorman, C. (2008). Cross-Sectional Versus Longitudinal Survey Research: Concepts, Findings, and Guidelines. Journal of Marketing Research (JMR), 45, 261-279.

Rosenstein, I. H. L. a. C. N. (1995). Race, Ethnicity, and Entrepreneurship in Urban America: Aldine Transaction.

Ruekert, R. W., Walker Jr, O. C., \& Roering, K. J. (1985). The organization of marketing activities: a contingency theory of structure and performance. The Journal of marketing, 13-25.

Rutihinda, C. (2008). EXPORT BARRIERS AND PERFORMANCE OF SMALL AND MEDIUM SIZE ENTERPRISES. Journal of International Business Research, 7, 57-63.

Shane, S. (2000). Prior Knowledge and the Discovery of Entrepreneurial Opportunities. Organization Science, 11, 448-469.

Sheng, S., Zhou, K. Z., \& Li, J. J. (2013). The effects of business and political ties on firm performance: Evidence from China. In: American Marketing Association.

Shoham, A., \& Albaum, G. S. (1995). Reducing the Impact of Barriers to Exporting: A Managerial Perspective. Journal of International Marketing, 3, 85-105.

Short, J. C., Ketchen, D. J., Shook, C. L., \& Ireland, R. D. (2010). The Concept of "Opportunity" in Entrepreneurship Research: Past Accomplishments and Future Challenges. Journal of Management, 36, 40-65.

Siegel, D. S., \& Renko, M. (2012). The role of market and technological knowledge in recognizing entrepreneurial opportunities. Management Decision, 50, 797-816.

Sinha, P., Wang, M., Scott-Kennel, J., \& Gibb, J. (2015). Paradoxes of psychic distance and market entry by software INVs. European Business Review, 27, 34-59.

Stam, W. (2010). Industry event participation and network brokerage among entrepreneurial ventures. Journal of Management Studies, 47, 625-653. 
Stottinger, B., \& Schlegelmilch, B. B. (1998). Explaining export development through psychic distance: enlightening or elusive? International Marketing Review, 15, 357-372.

Venkatraman, N. (1989). The concept of fit in strategy research: Toward verbal and statistical correspondence. Academy of Management Review, 14, 423-444.

Wei, L. I. (2007). Ethnic Entrepreneurship: Studying Chinese And Indian Students In The United States. Journal of Developmental Entrepreneurship, 12, 449-466.

Wu, F., Yeniyurt, S., Kim, D., \& Cavusgil, S. T. (2006). The impact of information technology on supply chain capabilities and firm performance: A resource-based view. Industrial Marketing Management, 35, 493-504.

Xiao, Z., \& Tsui, A. S. (2007). When brokers may not work: The cultural contingency of social capital in Chinese high-tech firms. Administrative Science Quarterly, 52, 1-31.

Yildiz, H. E., \& Fey, C. F. (2016). Are the extent and effect of psychic distance perceptions symmetrical in cross-border M\&As? Evidence from a two-country study. Journal of International Business Studies, 47, 830-857.

Zaheer, S., Lamin, A., \& Subramani, M. (2009). Cluster capabilities or ethnic ties Location choice by foreign and domestic entrants in the services offshoring industry in India. Journal of International Business Studies, 40, 944-968. 
Table 1. Demographic Information of Survey Participants

\begin{tabular}{|l|l|l|l|}
\hline \multicolumn{1}{|c|}{ Items } & Presence & \multicolumn{1}{|c|}{ Items } & Presence \\
\hline Number of & & Age of Firm: & \\
Employees: & $14.7 \%$ & 5 or less & $19.2 \%$ \\
25 or less & $27.1 \%$ & $6-10$ & $40.8 \%$ \\
$26-50$ & $22.4 \%$ & $11-20$ & $30.8 \%$ \\
$51-100$ & $23.3 \%$ & more than 20 & $9.2 \%$ \\
$101-250$ & $12.5 \%$ & & \\
\hline Export Experience: & & Export Dependence: & \\
3 years or less & $12.3 \%$ & $25 \%$ or less & $11.5 \%$ \\
$4-7$ years & $50.8 \%$ & $26-50 \%$ & $35.4 \%$ \\
$8-12$ years & $30.7 \%$ & $51-75 \%$ & $14.6 \%$ \\
13 years or more & $6.2 \%$ & more than $75 \%$ & $38.5 \%$ \\
\hline Number of Products: & & B2B Sales: & \\
5 or less & $32.3 \%$ & $25 \%$ or less & $11.5 \%$ \\
6- 10 & $25.4 \%$ & $26-50 \%$ & $17.0 \%$ \\
$11-20$ & $15.4 \%$ & $51-75 \%$ & $19.2 \%$ \\
$21-50$ & $16.1 \%$ & more than $75 \%$ & $52.2 \%$ \\
more than 51 & $10.8 \%$ & & \\
\hline
\end{tabular}


Table 2. Measures, loadings, and composite reliabilities of constructs and items

\begin{tabular}{|c|c|}
\hline Construct & Measure ${ }^{\mathrm{a}}$ (Loading) \\
\hline $\begin{array}{l}\text { International } \\
\text { Opportunity } \\
\text { Exploitation (IOE) } \\
\mathrm{CR}^{\mathrm{b}}=.834\end{array}$ & $\begin{array}{l}\text { To safeguard against respondents implicitly equating new opportunities } \\
\text { only with new products, we asked them to report on three different types } \\
\text { of opportunities: } \\
\text { new products and/or services }(.783) \\
\text { production technology }(.711) \\
\text { markets (.876) }\end{array}$ \\
\hline $\begin{array}{l}\text { Ethno-National Ties } \\
\text { (ET) }\end{array}$ & The ratio of Chinese population to the total population in each country \\
\hline $\begin{array}{l}\text { Technological } \\
\text { Turbulence (TT) } \\
\text { CR }=.800\end{array}$ & $\begin{array}{l}\text { The technology in our industry is changing rapidly. (.898) } \\
\text { If we don’t keep up with changes in technology, it will be difficult for } \\
\text { us to remain competitive (.588) } \\
\text { The production technology changes frequently and sufficiently (.762) } \\
\text { It is very difficult to forecast the technology development direction in } \\
\text { our industry* } \\
\text { The technological changes in our industry can bring many opportunities } \\
\text { for firms* }\end{array}$ \\
\hline $\begin{array}{l}\text { Psychic Distance } \\
\text { (PD) } \\
\text { CR }=.839\end{array}$ & $\begin{array}{l}\text { Level of economic and industrial development (.655) } \\
\text { Per capita income }(.750) \\
\text { Purchasing power of customers (.837) } \\
\text { Lifestyles (.758) } \\
\text { Communications infrastructure* } \\
\text { Marketing infrastructure* } \\
\text { Technical requirements* } \\
\text { Legal regulations* } \\
\text { Consumer preferences* } \\
\text { Level of literacy and education* } \\
\text { Language* }\end{array}$ \\
\hline $\begin{array}{l}\text { Export } \\
\text { Barriers (EB) } \\
\text { CR }=.804\end{array}$ & $\begin{array}{l}\text { For each statement listed below please indicate the extent to which it } \\
\text { poses a barrier for your company in its international operations: } \\
\text { Slow collection of payments from abroad (.701) } \\
\text { Limited and problematic communication with overseas customers (.878) } \\
\text { Difficulty in developing new products for foreign markets (.692) }\end{array}$ \\
\hline \multicolumn{2}{|c|}{$\begin{array}{l}\text { Fit Indexes: } \\
\text { Chi-square=129.417/71 d.f. } \\
\text { CFI=.921; IFI=.923; RMSEA=.080; SRMR=.0628 }\end{array}$} \\
\hline $\begin{array}{l}\text { NOTES: } \\
\text { a Measured on sevel } \\
{ }^{b} \text { CR = composite re } \\
{ }^{*} \text { dropped items } \\
\end{array}$ & $\begin{array}{l}\text { int Likert-type scale ( } 1 \text { = strongly disagree, } 7 \text { = strongly agree); } \\
\text { ility. }\end{array}$ \\
\hline
\end{tabular}


Table 3. Intercorrelations and shared variances of measures $(n=130)$

\begin{tabular}{|c|c|c|c|c|c|c|}
\hline & $\mathrm{F} 1$ & $\mathrm{~F} 2$ & $\mathrm{~F} 3$ & $\mathrm{~F} 4$ & $\mathrm{~F} 5$ & $\mathrm{~F} 6$ \\
\hline International Opportunity Exploitation (F1) & $\mathbf{. 6 2 9}$ & .016 & .048 & .022 & .033 & .001 \\
\hline Ethno-national Ties (F2) & .126 & $\mathbf{n / a}$ & .000 & .008 & .002 & .012 \\
\hline Technological Turbulence (F3) & .219 & .003 & .578 & .061 & .116 & .001 \\
\hline Psychic Distance (F4) & .148 & .092 & .246 & .567 & .010 & .005 \\
\hline Export Barriers (F5) & .182 & .048 & .340 & .101 & .580 & .061 \\
\hline Firm Size (F6) & -.038 & -.108 & .024 & .068 & -.247 & $\mathbf{n} / \boldsymbol{a}$ \\
\hline $\begin{array}{l}\text { Notes: Correlations are included in the lower triangle of the matrix and shared variances are } \\
\text { in the upper triangle. The average variance extracted for each construct is reported on the } \\
\text { diagonal. }\end{array}$
\end{tabular}


Table 4. Estimation result of moderating effect (Beta coefficients and t-values ${ }^{a}$ )

\begin{tabular}{cccc}
\hline Construct & Model 1 & Model 2 & Model 3 \\
\hline Firm Size & -.038 & -.009 & .033 \\
Ethno-national ties & & .097 & $.129^{\dagger}$ \\
Technological turbulence & & $.159^{*}$ & $.272^{* * *}$ \\
Psychic distance & .090 & $-.070^{* *}$ \\
Export barriers & .112 & $.200^{* *}$ \\
Ethno-national ties $\times$ Tech turbulence & & & $-.235^{* *}$ \\
Ethno-national ties $\times$ Psychic distance & & & $.227^{* *}$ \\
Ethno-national ties $\times$ Export barriers & & & $-.269^{* * *}$ \\
\hline $\mathrm{R}$ & .038 & .282 & .446 \\
Adjusted R & .001 & .043 & .146 \\
$\Delta \mathrm{R}^{2}$ & & .042 & .103 \\
\hline
\end{tabular}

${ }^{\mathrm{a}} \mathrm{DV}=$ Opportunity Exploitation, $\mathrm{t}$-values reported in parentheses, one-tailed tests. $\mathrm{n} / \mathrm{a}=$ not applicable

${ }^{\dagger} p<0.1$ (one-tailed), ${ }^{*} p<0.1 ;{ }^{* *} p<0.05,{ }^{* * *} p<0.01$ 
Figure 1. The Conceptual Model and Hypotheses

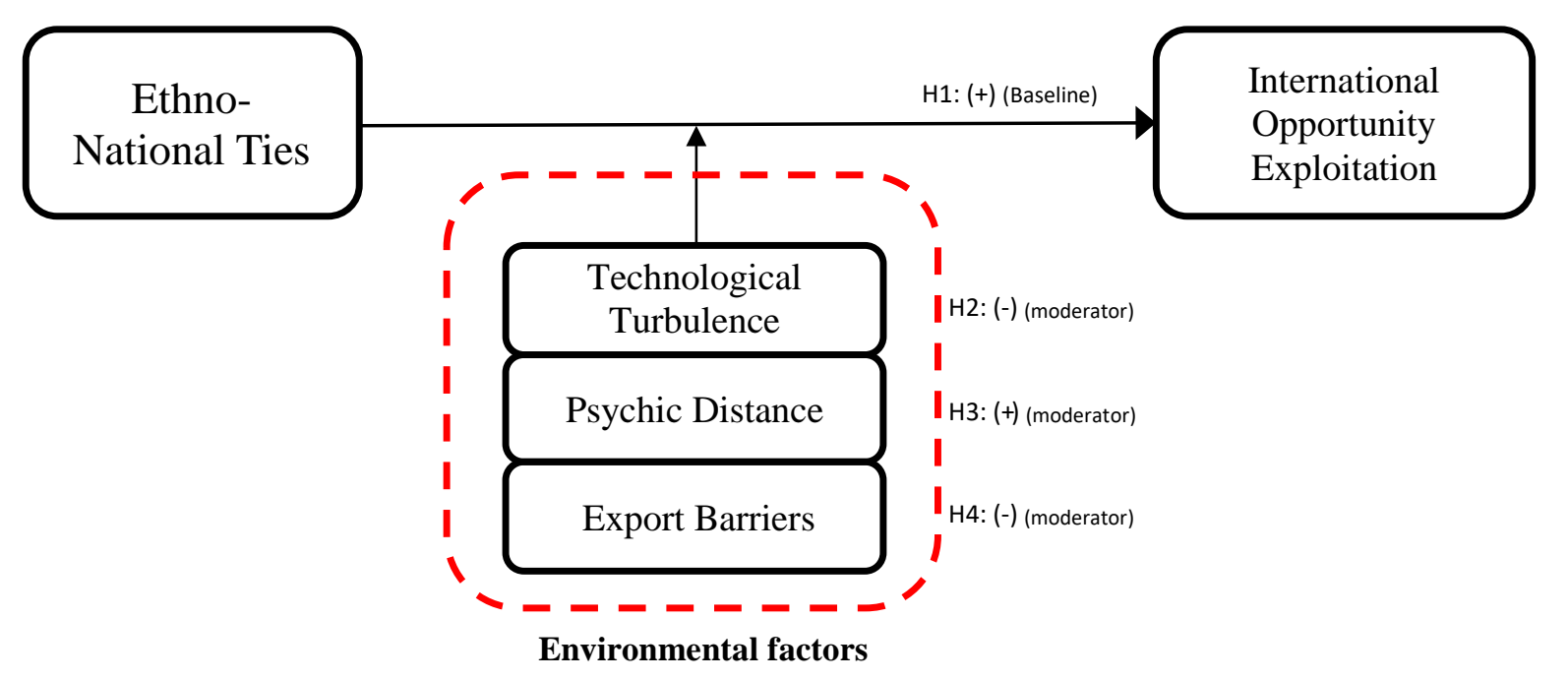


Figure 2. The result of moderation analysis

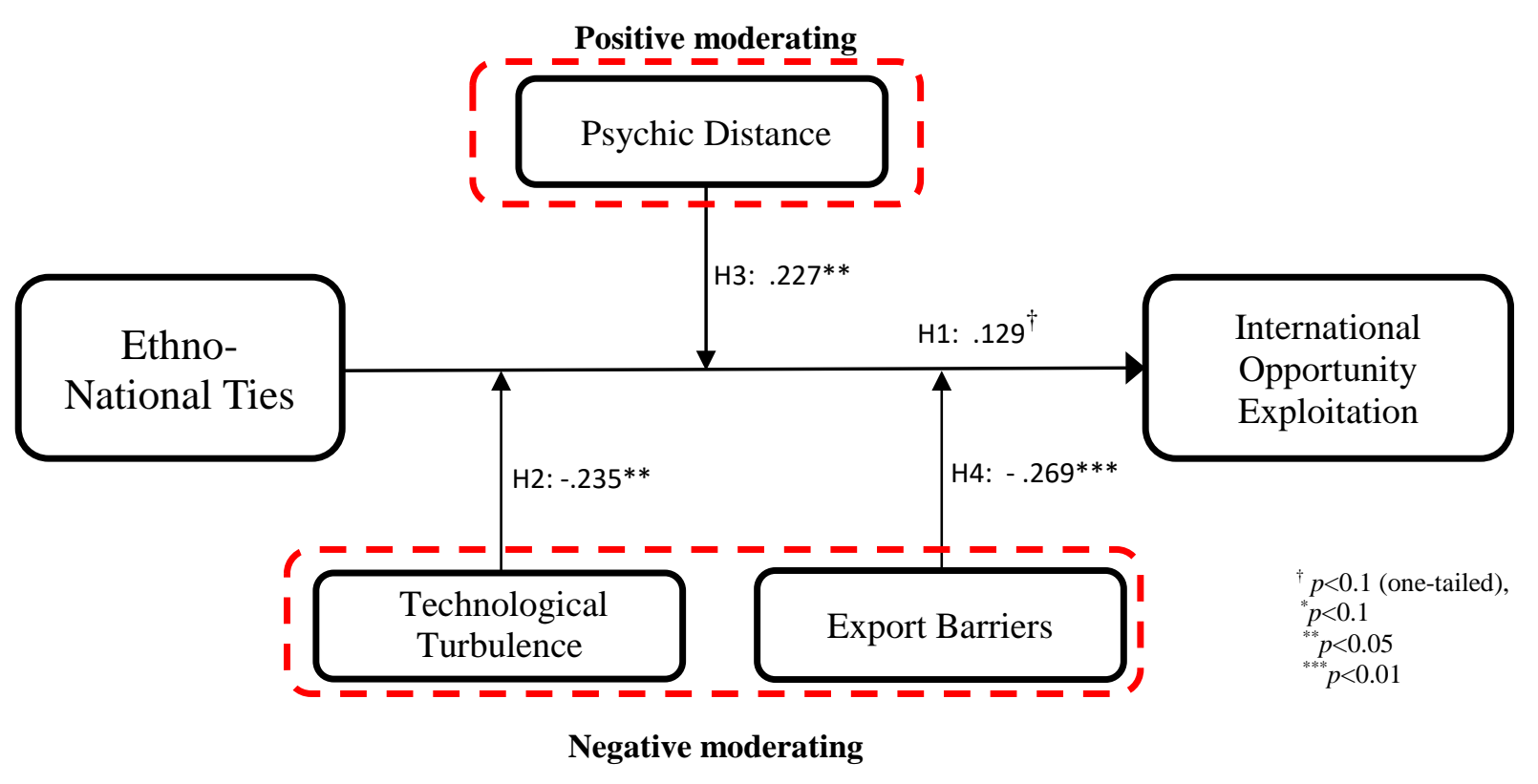


Figure 3. The Moderating Effect of Technology Turbulence

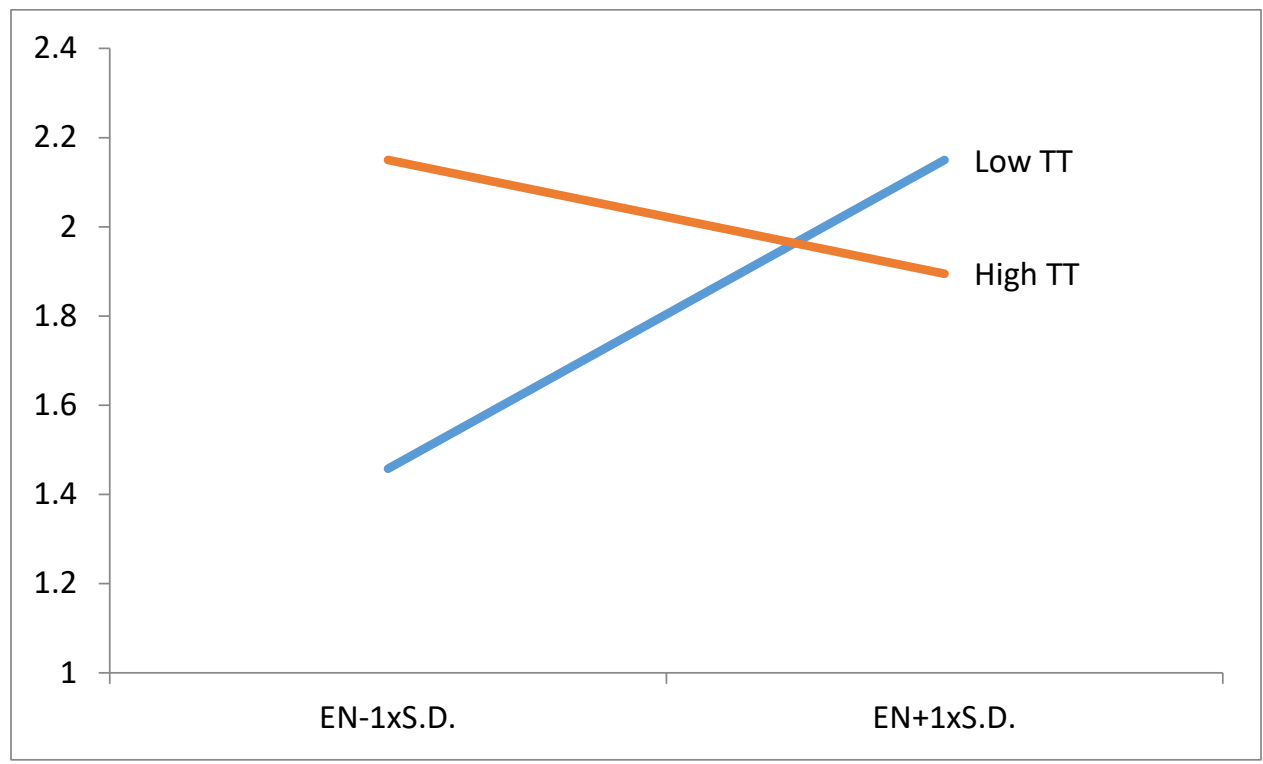


Figure 4. The Moderating Effect of Psychological Distance

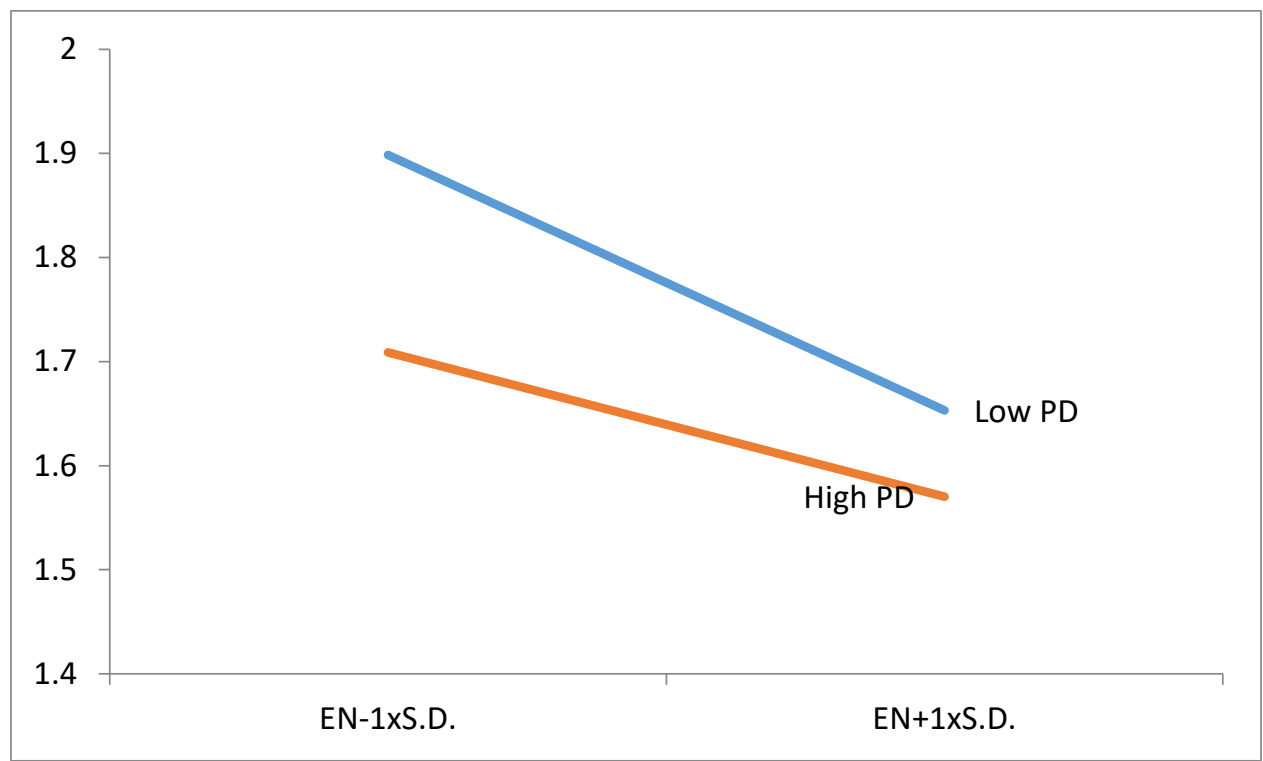


Figure 5. The Moderating Effect of Export Barriers

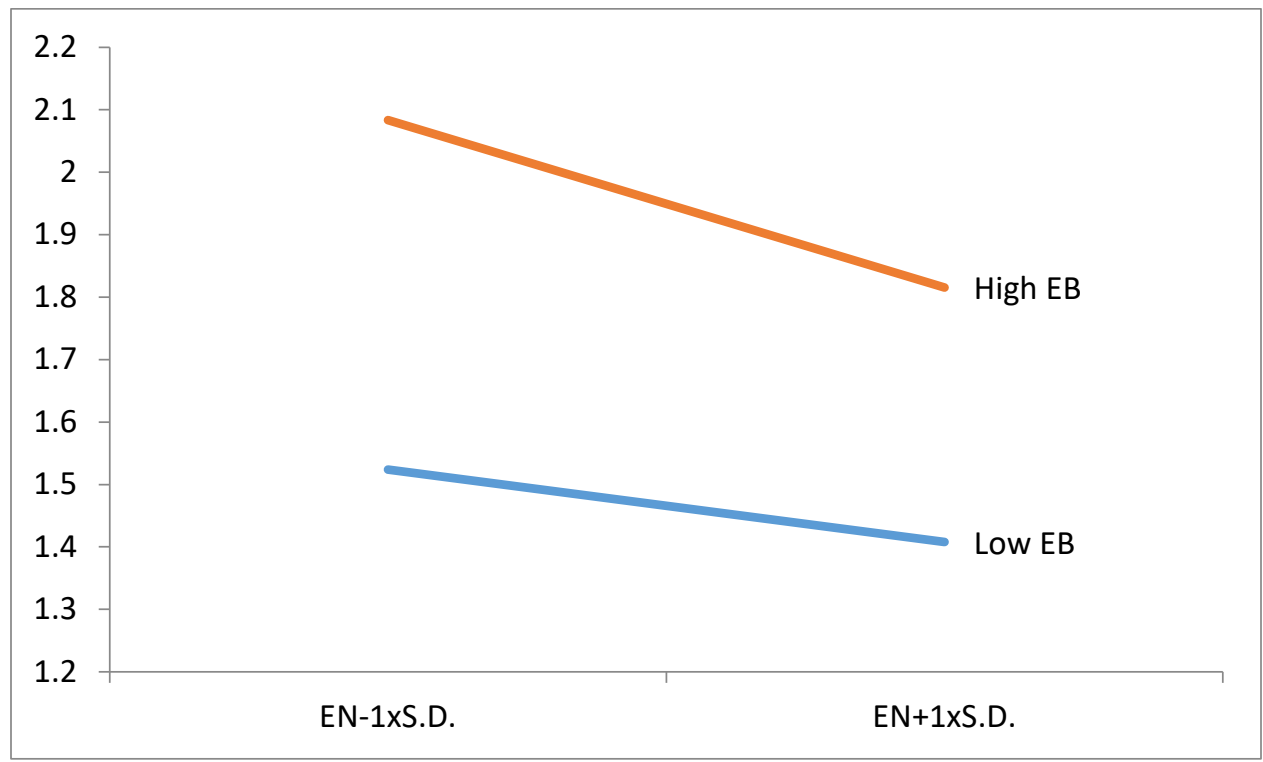

